\title{
An investigation on the role of Visual Merchandising Displays in the promotion of traditional fabrics. An evidence from retailing the Asante Kente fabrics in Ghana.
}

\author{
Isaac Ofori-Okyere \\ Department of Marketing and Strategy \\ Takoradi Technical University. \\ Safo Ankama Kweku \\ Department of Textiles \\ Takoradi Technical University
}

\begin{abstract}
The fierce competition and the similarity of competing merchandise characterised modern fashion industry impel fabrics retailers to utilise various visual merchandising displays (VMDs) to improve the desirability of their products and to achieve differentiation of their offerings from competition. This has led to this study investigating on the role played by the various VMDs in the promotion of Asante Kente fabrics. Reviewed literature comprised: the Kente apparel, various VMDs adopted by retailers to promote products, and benefits derived by apparel retailers from adopting VMDs. An explorative research and qualitative data were gathered by means of projected images and focus groups discussions and direct observations. The data were analysed by means of thematic analysis. Findings indicated that respondents have knowledge on certain VMDs both exterior and in-store, whereas, other VMDs were considered not appropriate in their line of business. This is to say that all the respondents contacted on the field agreed to certain positions established by extant theories regarding the adoption of VMDs and the role they play in promoting apparels in retail shops
\end{abstract}

Key Words: Kente fabrics and apparels, Visual Merchandising Displays, Ghana.

\section{INTRODUCTION}

Kente cloth, known as nwentoma in the Akan language, is a type of silk and cotton fabric made of interwoven cloth strips. 'Kente' is a derivative from the Akan word for basket, kenten or kenten (Kwekudee, 2012) and is native to the Akan ethnic group of Southern Ghana. Specifically, Asante "KENTE", a brilliantly colourful fabric, is entirely hand-woven in the Ashanti Kingdom, in the Kwabre areas of the Ashanti Region (e.g. Bonwire, Adanwomase, Sakora Wonoo, and Ntonso). It is usually identified by its dazzling, multi-coloured patterns of bright colours, geometric shapes and bold designs (Ofori-Ansa, 2009). Fashion greats and traditional textile publicists maintain that the brilliant colours and intricate designs always associated with Kente have unquestionably made this fabric the best known of all Ghanaian, and perhaps even all West African textiles because it is woven in large quantities, exported to more places, and incorporated into greater variety of forms than any other African fabric. Traditional apparel theorists (e.g. Asamoah -Yaw, 1992) stress that the Asante Kente represents the creative, thoughtful or designer's woven cloth'. What makes it more beautiful and most preferred form of traditional apparel is that every design incorporated in Asante 
Kente has a story with a philosophical meaning, giving each cloth its own distinction. Avins and Quick (1998) add that the Kente apparel has also captured the attention of visitors since at least 1817 hence making it a traditional fabric synonymous with exquisites attributes such splendor and ostentation, extravagant price and incredible size and weight.

Functionally, the cloth is woven according to gender. A woman's Kente is worn in three pieces, one piece is wrapped around the lower body in a tubular form as long skirt and held down at the waist with a scarf. Alternatively, the piece of cloth for the women is sewn into an ankle length skirt held at the waist with string of cloth or elastic band. The second piece is also sewn into fashionable Kaba (blouse). Both male and female Kente may bear similar features such as motifs, arrangement and colours yet they have distinct characteristics (Badoe, 2005). Conversely, the male's Kente cloth is worn by draping it loosely around the body from the shoulders down with the ends held over the left shoulder (NB: over the right shoulder is culturally inappropriate) in the manner of the Roman toga (Bowdich, 1966 as cited in Badoe, 2005). In Ghana, its usage cannot be over stated. The colourful Kente cloth is worn by guests in all functions and ceremonies (e.g. state functions-independence day ceremonies, oath swearing of public officers, graduation and matriculation ceremonies of students, Church services, weddings and engagements, beauty contests, etc.). In recent times, fashion stylists in their quests of popularising the apparel and making it affordable to all have produced scores of assorted ornaments from Kente (e.g. shirts, shorts, hats, luggage or carrier bags, graduation stoles, mufflers, flying ties, bangles, headgears, Kente casuals, etc.).

This study proceeds from a consumer response-centred approach to investigates visual merchandising displays (VMDs) used by retailers to promote the Kente cloth. Modern retail fashion business is characterised with fierce competition and the similarity of merchandise impel players in the fashion industry to utilise various visual merchandising displays (VMDs) to improve the desirability of products. Findings in retail market research indicate that retailers across the globe face a challenge when it comes creating competitive advantages and to achieve differentiation for their brands (Shu-Luan, n.d.). In the specific case of apparel retailers, their major tasks transcend beyond improving quality of their products, to adopting a strategy of shaping a well-designed store atmospherics for the purposes of attracting patrons to their business space.

Specifically, retailers like the ones found in the apparel industry strategically design their shops to attract buyers into their shops, assisting them to select the products they need and to inspire them to make planned, unplanned and spontaneous purchases and ultimately provide them with an enjoyable shopping experience (Levi and Weitz, 2009). The type of environmental stimuli the VMDs adopted by apparel retailers create could have an effect on consumers' perceptions, that is "... a practice where a visitor to the shop observes, selects, organises and reacts to environmental stimuli in a significant way..." (Du Plessis and Rousseau, 2003). Thus it is held that successful VMDs create favourable effect on consumers' emotion; hence they sometimes purchase products unconsciously depending on their current mood (Hefer and Cant, 2013).

In practice, it can be maintained that retailers sometimes have at their disposal the "usual" elements of brand identity: name, symbol, packaging, and advertising. Extant literature explain that retailers can additionally draw on those dimensions that have been identified in studies of store image (Davies and Ward, 2002 - drawing on the work of, for example, Bloemer and de Ruyter, 1998; Grewal, Krishnan, Baker \& Borin,1998; Lindquist, 1974; Martineau, 1958; Porter and Claycomb, 1997). Merchandise (assortment; quality; brand mix; and price); store (location; environment - internal and external; atmosphere; and name/fascia); Service (personnel; and 
levels and quality) and Promotion (advertising/public relations; and in-store). These elements mean "design" are brought to the fore and, in particular, it is visual design that is emphasised (Kent, 2003). The significance of the visual is also reflected in the attention always paid to the physicality of retail provision and can be seen in the extensive literatures that have developed around particular issues, for example, of "retail location"; "retail atmosphere"; "servicescape" and "merchandise selection and display".

Despite the various roles played in the apparel retail industry, VMDs as strategic promotional tool is referred to as a neglected field in fashion marketing research (Buttle,1988), which this 'neglect' of the retail front is considered as the face of Kente apparel brands promoted by retailers in Ghana. Sharing similar opinion, Lea-Greenwood (1998) stresses that as a promotional strategy adopted by retailers in the apparel industry, VMDs have not received much attention in the academic literature. Bastow-Shoop et al., (1991) posit that as a promotional strategy, VMDs is rated as second only to effective customer relations by retailers. The current authors perceive that this neglect though not regarded as total, does not suggest that this area of fashion is unworthy of academic research. Kim (2003) argues that it may indicate that since VMDs comprise perceptions and aspects of creativity, it is perceived as an area difficult to test, researchers may be challenged when it comes to presenting meaningful analyses for it. A notable exception has been within the Ghana's fashion based literature, where a limited number of texts have been devoted to the subject. These though are primarily practitioner-based, highlighting again a deficiency of attention from retail academics.

It is the light of the above mentioned developments that the current researchers used this study to represent a small step towards addressing this lack. It investigates the role played by VMDs in the promotion of Asante Kente apparels in Ghana. The study sought to answer the following research questions: (1). How can VMDs adopted by Kente fabric retailers to promote their products be determined? (2). what benefits do Kente apparel retailers derive from adopting VM as their promotional strategies in Ghana?

\section{What is Visual Merchandising (VM)?}

\section{LITERATURE}

VM has over the years received diverse definitions from different authorities with many agreeing on the basic key terms like display, presentation of products to customers. Ebster and Garaus (2011) see visual merchandising as "the art and science of presenting products in the most visually appealing way", emphasizing on the communication with the customers through images and presentations. Diamond and Diamond (2003) also define VM as the presentation of a store and its merchandise in ways that aim to attract the attention of potential customers and motivate them to make purchases.

These definitions have been extended by Bastow-Shoop, Zetocha, and Passewitz (1991) who maintain that VMDs is everything the customer sees, both exterior and interior, that creates a positive image of a business and results in attention, interest, desire and action on the part of the customer. Visual merchandising is therefore concerned with both how the product and/ or brand are visually communicated to the customer and also whether this message is decoded "appropriately" (Wanninayake and Randiwela, 2007). Though Wanninayake and Randiwela has contributed towards the definition of the concept VMDs but they focused on the visuals aspects of the concept by overlooking the role other sensory organs like hearing, smelling, etc. play in presenting the merchandise to the customer. Judging from the above definitions, the current researchers also see VM as the physical presentation of products and services and the design of a place of business for the purpose of increasing sales. This is because an effective 
and more efficient VMDs is often referred to as the silent salesperson communicating to the customers with its purpose of attracting them to the merchandise for closer examination that leads to sales.

\section{Visual Merchandising Displays/ Elements}

The design of a retail environment is related to the store atmosphere creation (Law, Wong, and Yip, 2012). Kotler (1974) defined store atmosphere as the quality of the surrounding space. It is an important issue for inducing the desired affective response of consumers and aims to enhance purchase probability. In today's keen competitive environment store image and atmosphere are recognized by retailers as important factors influencing customers' decision making processes (Hartman and Spiro, 1995). More specifically, atmospherics is an effort to design buying environment to produce specific emotional effects in the buyer that enhance his purchase probability (Kotler, 1973). These atmospherics also called "good" interior design within a store can maintain customer interest, encourage customers to lower their psychological defenses and make a purchase by (Walters and White, 1987; Bitner, 1992; Omar 1990 and Davies and Ward, 2002). The impact of a pleasant store atmosphere is also positively related to customer satisfaction (Spies, Hesse, and Loesch, 1997). Atmospheric stimuli which please the actual and emotional needs of consumers enhance the degree of consumer participation in a store, leading to favourable purchasing behaviours (Wright, Newman, and Dennis, 2006).

Mills, Paul, and Moorman (1995) suggest that "visual merchandising ranges from windows/exterior displays to interior displays including form displays and floor merchandising along with promotion signage. "The presentation of a store/brand and its merchandise to the customer is made possible through the teamwork of the store's advertising, display, special events, fashion coordination, and merchandising departments in order to sell the goods and services offered by the store/company.

Farese, Kimbel, and Woloszyk, 2003) further divided the elements of VMDs into four to comprise of storefront (signs, marquee, entrances and window displays), store layout, store interior (fixtures), and Store display. On the view of Law, et al. (2012), the work of Farese et al was summed to include store exterior and interior as the two major areas covered in Visual Merchandising with a variety of components (colour combination, product placement, lighting arrangement, layout and highlight design, mannequin and props selection, fixtures and fittings selection) are involved in creating a favourable shopping atmosphere.

Babin, Hardesty, and Suter, (2003), following suit found that the combination of colours and lighting plays a critical role in influencing the purchase intention of consumers and store patronage. Intangible store elements, such as sprayed fragrance, can stimulate one's affective state and help boost mental imagination (Fiore, Yah, and Yoh, 2000). Chebat, Chebat, and Vaillant (2001) found that appropriate music can affect the cognitive activity of consumers. A positive imagery also helps in associating a better cognitive experience between consumers and products, and intensifying purchase intentions (Mandler, 1982; Macinnis and Price, 1987; Meyers-Levy and Tybout, 1989).

They are known as visual merchandising practices to comprise of focused merchandising, intelligent store design and layout, product displays, packaging, and signage. This because retailers can use it to help customers find the right products (Baker, Grewal, and Levy, 1992). (Mills, ET al.1995). It comprises of window/exterior displays to interior displays including form displays and floor/wall merchandising as well as promotion signage Kotler (1974) explained store atmosphere as the quality of the surrounding space. It is an important issue for inducing the desired affective response of consumers and aims to enhance purchase 
probability. Based on Kolter's thought, Donovan and Rossiter (1982) extended the concept with physical in-store variables (layout, architecture etc.) and the influence of social factors (type and behaviour of people). A number of the internal store aspects identified above, e.g. merchandise, atmosphere and in-store promotion, are reminiscent of Omar's (1999) classification of interior display types: merchandise, point-of-sale and architectural.

\section{Benefits to be derived by retailers from adopting VM as their promotional tool}

In recent years, there has been a growing recognition that store interiors and exteriors can be designed to create specific feelings in shoppers that can have an important cuing or reinforcing effect on purchase (Kotler, 1973-1974). Atmospheric stimuli which please the actual and emotional needs of consumers enhance the degree of consumer participation in a store, leading to favourable purchasing behaviours (Wright et al., 2006). The presentation of a firm and its merchandise and attract potential customers and facilitate purchasing (Diamond and Diamond, 2003). Stores with attractive displays or attractive de'cor might reduce psychosocial risk related to purchasing (Mitchell, 2001). The impact of a pleasant store atmosphere is also positively related to customer satisfaction (Spies et al., 1997). Wright et al.,( 2006) also considers the atmospheric stimuli of VMDs as able to pleasing the actual and emotional needs of consumers enhance the degree of consumer participation in a store, leading to favourable purchasing behaviours.

As tactics it is used by retailers to attract customers to the stores. It will stimulate them to choose the most liked store, spend more time in it, and examine the products and eventually resulting in a purchase (Gajanayake, Gajanayake, and Surangi, 2011). Visual merchandising is used to create a positive shopping experience - and that makes customers want to return (Farese ET al.2003). Besides, visual merchandising is also a powerful marketing tool as an external motivator in the consumer's impulse buying behaviour. Indeed, impulse buying is significant for sales revenue; in fact it represents a substantial volume of goods sold every year (Bellenger, Robertson, and Hirschman, 1978; Clover, 1950; Cobb and Hoyer, 1986; Kollat and Willet, 1967). Visual merchandising enhances the attractiveness of a store and its perceived image from the viewpoint of customers. A positive mood serves as a contextual cue for evaluating the perceived quality, image of a product and store, and purchase intention (Bakamitsos, 2000). The impact of a pleasant store atmosphere is also positively related to customer satisfaction (Spies et al., 1997). Atmospheric stimuli which please the actual and emotional needs of consumers enhance the degree of consumer participation in a store, leading to favourable purchasing behaviours (Wright et al., 2006).

\section{METHOD}

The study adopted exploratory design to scrutinise insights into general nature of the research problem as has been indicated by Tustin, Ligthelp and Martins (2005). This was to find out the extent to which the respondents agree or disagree regarding the fact that various VMDs play a key role in the promotion (retailing) of the Asante Kente in Ghana. Due to the exploratory nature of the study, non-probability sampling method was used to get the samples grouped in a process that does not give all the individuals in the population an equal chance of being selected (Tustin et al, 2005). In this case, subjects were selected on the basis of their accessibility and through purposive approach the purpose (personal judgment) of all the researchers (Zikmund and Babin, 2010)

On the field, it was observed that all the weavers or producers/ retailers have formed associations. Example in Adawomase Township, Adawomase Kente Weavers Association (AKWA) and Adawomase Royal Kente Weavers Association (ARKWSA) exist as Kente 
producers/retailers association. So members and leadership of such associations assisted the researchers (in the form of snowballing / referral services) when they needed to purposively sample participants for the FGDs. As a traditional occupation, the Kente trade comprise individuals who perform varied roles before the finished product gets into the hands of the final consumer. One person can be seen as a designer (in-charge of motifs, arrangement and the choice of colours), a weaver, a producer and the same time a retailer. The researchers' request to undertake this study involved seeking to negotiate access to a range of participants based on the purposive and convenient sampling of designers, weavers, producers / retailers. In order to select such a sample the researchers required access to the list of members for all the Kente associations located in each of the towns. This request made by the researchers determined precisely how they required the sample to be selected.

Hence, the criteria used to purposively sampling of participants to participate in this study included:

- Kente apparel producers / retailers who have their business located in Bonwire, (in the Ejisu Juaben District), Adawomase, Sakora Wonoo, and Ntonso townships (also all in the Kwabre East District).

- End users of Kente apparel who buy the products from the retailers in Bonwire, Adawomase, Sakora Wonoo, and Ntonso townships.

- Individuals with the time and the willingness to participate in the study particularly in the Focus Groups (Discussions and interviews).

- Both retailers and an end user with prior knowledge on the adoption of VMDs in the retailing of apparels.

Data was collected by the use of FGDs, which according to Zikmund and Babin (2010) are considered as unstructured, free flowing interview with a small group of people, usually between six and ten participants. This was supported with illustrations, which were openended questions that asked participants questions relating to the topic under study (Hodder, 1994), which in this case referred to the various VMDs adopted by the Kente fabric retailers in Bonwire, Adawomase, Sakora Wonoo, and Ntonso townships in the promotion of the product. These satellite towns were selected for this study, because it is believed that they constitute the towns in the Ashanti Kingdom, precisely in the Ejisu Juaben District and Kwabre East District where the Kente cloth (apparel) is predominantly noted for its hand-woven nature hence the promotion of the Kente trade by the people. In all, forty (40) participants (ten participants in each focus group) were used to collect data. That is, ten (10) participants selected from each town were contacted and invited to participate in the study which they all expressed willingness and acceptance to participate after researchers explained the essence of the study to them. All these respondents were selected because they remain the right individuals with the right responses to provide to carry out this study (Holme and Solvang, 1997).

In each town, two forms of data were compared with one another to gain the most preferred data possible from each participant. The focus groups were based on the adoption of the VMDs adopted by the Kente retailers to promote the products to their customers. Photographs of apparel retail shops were projected to the participants in the focus groups. With the researchers acting as the moderators, series of questions derived from the research objectives were posed to the participants. The structure of the questions for the focus groups were as follows:

1. What VMDs are adopted by retailers to promote their Kente fabrics?

2. What benefits do Kente fabric retailers found in this town derive from adopting VMDs as their promotional strategies? 
All discussions and interviews were put on tape and lasted for two hours. The interview content was transcribed from the Akan language (Asante Twi) to English. The first two interviews were adopted as a blueprint to establish the codes, concepts and inter-relationships for open coding. The third focus group interview found that participants with prior knowledge in VMDs tend to accept the subject under discussion. Thus, attention was paid to participants with or without a strong knowledge sense in VMDs.

Thematic analysis was used to analyse data for this study due to the contextual nature. Tesch, (1990) explain thematic analysis as an activity in qualitative research which involves a thorough search through qualitative data to identify any recurring patterns. For the purpose of this study, these patterns were then sorted into themes and categories. It is thus a process that provides organisation and description of qualitative data in detail (Braun and Clarke, 2006).

\section{RESULTS}

At this stage, the conclusion of the questions posed to participants during the FGDs were examined in two main themes and their underlying categories as outlined by Tesch's 1990 model (thematic analysis).

Theme 1: VMDs adopted by Kente apparel retailers to promote their products.

Samples of the various VMDs were projected to the participants. The purpose for the projections was to find out the extent to which participants were aware about the existence of each display element and the roles they play in the promotion of Kente products by the retailers.

Two categories emerged from this theme.

First category: The participants displayed their knowledge about what constitute interior display.

Participants have knowledge on certain interior VMDs which included colours and lighting, sprayed fragrance, intelligent store designs and layouts, product displays, packaging, and signage. The following quotation were taken from the FGDs:

- I have heard of sprayed fragrance.

- I have come across different lightings been used by stores in the big cities and movies.

- I have seen different types of product displays in shops in the big cities.

Secondary category: Participants agreed to the fact that they have knowledge on exterior displays.

The exterior displays participants expressed knowledge on include store windows, signage, marquees and awnings. The following quotations were taken from the discussions that ensued between them and the moderators.

Store windows are used for sales promotions, image-building, seasonal changes, new arrivals and high demand items.

A fresh and exciting face can be constantly presented using a store window. Signage provides information on product related features/ benefits/prices. 
It needs to be noted however, that factors such as space, availability of VMDs and cost to be incurred to obtain them from the market always deter retailers from accessing them.

Theme 2: Benefits of VMDs to Kente fabric retailers in Ghana

After the moderators of the FGDs projecting various images on VMDs to participants, varied assertions were made concerning the benefits retailers would derive from adopting VMDs in their stores.

due to the competitive nature of the Kente fabric business found in the four towns, attention of retailers should be paid to well-designed store interiors and exteriors for the purposes of creating specific feelings in shoppers that can have an important cuing or reinforcing effect on purchase.

The following three categories emerged from the theme:

First Category: The participants agreed that the VMDs are capable of attracting customers to a Kente fabric store.

The FGDs found that the strategic VMDs in an apparel store attract potential customers and facilitate purchasing.

However, there are other factors like branding in the form of recognised store name, symbol, packaging, and advertising, attractive de'cor, quality products, pricing, promotion, location, customer service or support that also affect the final decision to be taken by customer.

Pleasant store atmosphere is capable of impacting positively on the satisfaction of Kente apparel shoppers. This illustrates practically that VMDs influence buying behaviours of Kente shoppers. Quotations that were taken from the data to exemplify findings include:

- Good displays attracts me to a store.

- I can do impulse buying based on good VMDs in a store.

- Dramatic and experiential displays can lead me buy the fabric finally.

Second Category: VMDs create a positive shopping experience The participants during the FGDs agreed that VMDs provide positive shopping experience for Kente fabric shoppers. However, store owners or retailers have roles to play to ensure a conducive shopping environment that provide such experience. These quotations validate this category:

- I think it can inspire me, get attracted to most liked Kente store.

- I can spend some times in it for a while.

- I can examine different kinds of Kente fabric before making a final purchase.

Third Category: VMDs produce specific emotional effects and create positive mood that serves as a contextual cue for evaluating the perceived quality of the apparel

Although VMDs are capable of attracting customers to a Kente fabric store, and provide positive shopping experiences for the shoppers, retailers should take into consideration the positive mood a good shopping atmosphere provides since it helps in evaluating the perceived 
quality of the apparels, the image (both products and store), and purchase intentions. The following quotations were taken from the FGDs to validate this category:

- A pleasant store atmosphere gives me psychological satisfaction.

- Good VMDs enhance the degree of my participation in a store.

- To say wow and pay for it depends on good VMDs visible.

\section{DISCUSSIONS AND CONCLUSIONS \\ VDMs adopted by retailers in the promotion of the Kente fabric}

Through discussions and interviews making up of the FGDs, it was revealed that the participants had knowledge on few VMDs which include: Their knowledge on exterior presentation include signage, banners, marquees, and awnings. Direct observation revealed non-adoption of awnings, window displays as exterior VMDs for all the Kente shops located in all the four towns visited.

In-store visual merchandising displays adopted by the retailers included shelves, music, fixtures and fittings selection, products display. This is said to be congruent with the positions of authorities (e.g. Baker, Grewal, and Levy, 1992; Farese, Kimbel, and Woloszyk, 2003) as established in literature. The following VMDs were found not to be adopted by retailers in their quests of promoting the Kente fabric: Store's advertising, packaging, lighting arrangement, sprayed fragrance, visual effects, special events, in-store promotion, point-of-sale, and in-store promotion signage, and store layout. This is to say that responses from the field were incongruent with the positions of extant theories (e.g. Fiore et al., 2000; Law, et al., 2012). Respondents explained further that the Kente fabric is enjoying automatic promotion in the marketplace due to its nature of being considered as a fabric of royalty and regalia

\section{Benefits derived by retailers in visually merchandising the Kente apparel}

During the FGDs, it was revealed that effective VMDs attract customers to visit the stores, provides positive shopping experiences and can lead to impulse buying. VMDs can stimulate customers, get them attracted to most liked Kente store by spending some times in there for a while by examining different kinds of Kente fabric before making a final purchase. A pleasant in-store atmospherics provide shoppers psychological satisfaction and enhance the degree of their participation in the stores. These responses from the field are said to be agreeing with the positions of existing theories (e.g Bellenger, Robertson, and Hirschman, 1978; Clover, 1950; Cobb and Hoyer, 1986; Kollat and Willet, 1967; Farese et al., 2003; Wright et al., 2006; Gajanayake, Gajanayake, and Surangi, 2011). These are a reflection on the key role played by the adoption of VMDs in the promotion of the Kente fabric in the Ashanti Kingdom.

The study concludes that Kente apparel retailers found in both Ejisu Juaben and the Kwabre Districts have knowledge on and adopt few VMDs in their business with majority of them considered as not appropriate in their line of business. They also agreed that they derive benefits for adopting VMDs in the promotion of their products. This is to say that all the respondents contacted on the field agreed to certain positions established by extant theories regarding the adoption of VMDs and the role they play in promoting apparels in retail shops.

\section{RECOMMENDATIONS}

It is recommended that in their quest of promoting the Kente fabrics, there should be the need to adopt Integrated marketing communications, that is a marketing programme where retailers tactically co-ordinate all their marketing communications tools to deliver a clear, 
consistent, credible and competitive message about the business and the Kente products they seek to promote.

Future researchers are advised to look at the role integrated marketing communications (IMC) play in the marketing of other fashion apparels. Lastly, the study being qualitative was carried out in the Ashanti Kingdom (i.e. in all the four towns noted for the production of Kente), it is advised that future researchers should replicate the study in other regions noted for the promotion and marketing of the apparel with the results also quantified.

\section{References}

1. Avins, L. and Quick, B. D. (1998). Wrapped in Pride: Ghanaian Kente and African American Identity, UCLA Fowler Museum of Cultural History, the Newark Museu

2. Babin, B., Hardesty, D. \& Suter, T. (2003), "Color and shopping intentions: the intervening effect of price fairness and perceived effect", Journal of Business Research, 56(7) 541-51.

3. Badoe, W. (2005). Analytical Study of the Structural Patterns of Asante Kente. KNUST Mphil Thesis.

4. Bakamitsos, G.A. (2000). "Mood effects on product evaluations: when and how does mood makes a difference", (Doctoral dissertation). Available from Northwestern University Dissertations and Theses database.

5. Baker, J., Grewal, D. \& Levy, M. (1992). An experimental approach to making retail store Environment Griffitt, William (1970), “Environmental Effects on interpertal Decisions," Journal of Retailing, 68(4).44560.

6. Bastow-Shoop, H., Zetocha, D. \& Passewitz, G. (1991).Visual merchandising a Guide for Small Retailers. North Central Regional Center for Rural Development RRD 155

7. Bellenger, D.N., Robertson, D.H. \& Hirschman, E.C. (1978). Impulse buying varies by product. Journal of Advertising Research, 18, 15-18.

8. Bloemer, J. \& de Ruyter, K. (1998), “On the relationship between store image, store satisfaction and store loyalty”, European Journal of Marketing, 32(5/6) 499-513.

9. Braun, V. \& Clarke, V. (2006). Using thematic analysis in psychology. Qualitative Research in Psychology, 3: $77-101$

10. Buttle, F. (1988). Merchandising. European Journal of Marketing, 18 (5), 4-25.

11. Chebat, J.C., Chebat, C.G. \& Vaillant, D. (2001). “Environmental background music and in-store selling”, Journal of Business Research, 54, 11-123.

12. Christensen, L.T., Firat, A.F. \& Torp, S. (2008). “The organization of integrated communications: toward flexible integration", European Journal of Marketing, 42 (3/4) 423-52.

13. Cobb, C.J. \& Hoyer, W.D. (1986). Planned versus impulse purchase behavior. Journal of

14. Retailing, 62, 384-409.

15. Clover, V.T. (1950). Relative importance of impulse buying in retail stores. Journal of Marketing. 25, 6670 .

16. Darden, W.R., Erdem, O. \& Darden, D.K. (1983). A comparison and test of three casual models of patronage intentions. Patronage Behavior and Retail Management, New York, NY: North Holland.

17. Davies, B.J. \& Ward, P. (2005). Exploring the connection between visual merchandising and retail branding: An application of facet theory International Journal of Retail and Distribution Journal of Management 33 (7), 505-513.

18. Diamond, J. \& Diamond, E. (2003), Contemporary Visual Merchandising Environmental Design. 3rd ed., Prentice Hall, Upper Saddle River, NJ. 
19. Donovan, R.J. \& Rossiter, J.R. (1982). "Store atmosphere: an environmental psychology approach", Journal of Retailing, 58 (1), 34-57.

20. Du Plessis, P. J. \& Rousseau, G. G. (2003). Buyer behaviour: A multi-cultural approach. 3rd ed. South Africa: Oxford University Press.

21. Ebster, C., \& Garaus, M. (2011). Store Layout and Visual Merchandising. New-York: Business Expert Press

22. Farese, L., S., Kimbel, G., \& Woloszyk, C.A. (2003). Marketing Essentials. Glencoe /MacGraw-Hill, California.

23. Fiore, A.M., Yah, X. \& Yoh, E. (2000). "Effect of a product display and environmental fragrancing on approach responses and pleasurable experiences", Journal of Psychology and Marketing, 17 (1), 27-54.

24. Frings, G.S., (1999). Fashion: From concept to customer (6th Ed). Upper Saddle River, New

25. Jersey: Prentice-Hall.

26. Gajanayake, R., Gajanayake, S. \& Surangi, H.A.K.N.S. (2011). The impact of selected Visual Merchandising Techniques on patronage intentions in Supermarkets (Study Based on Colombo District). Paper presented at 2nd International Conference on Business and Economic Research Proceeding 1130

27. Grewal, D., Krishnan, R., Baker, J. \& Borin, N. (1998). "The effects of store name, brand name and price discounts on customers' evaluations and purchase intentions", Journal of Retailing, 74 (3), 331.

28. Ha, Y., Kwon, W., \& Lennon, S.J. (2007). Online visual merchandising (VMD) of apparel web sites. Journal of Fashion Marketing and Management 11 (4), 477-493.

29. Harris, K. (1998). "Merchandising tips for the web”, SGB: Sporting Goods Business, 31(17), 12-13.

30. Hefer, Y and Cant, M.C. (2013).Visual Merchandising Displays' Effect on Consumers: A Valuable Asset or an Unnecessary Burden For Apparel Retailers International Business \& Economics Research Journal October 2013 Volume 12, Number 10

31. Hodder, I. (1994). The interpretation of documents and material culture. In Denzin, N. K. \& Lincoln, Y. S. (Eds), Collecting and interpreting qualitative materials (703-716). California: Sage Publications.

32. Holme, I.M. \& Solvang, B.K. (1997). Forsingsmetodik: Om kvalitativa och kvalitativa metoder. Studentlitteratur. Lund

33. Iqbal, A., Umer, H., Magbool, A., Sunil, N., \& Pillai, K.R. (2011). Visual Merchandising and Customer Appeal Birla Institute of Technology Kingdom of Bahrain.

34. Kim, J. (2003). Apparel Impulse Buying Behaviors In Relation To Visual Merchandising. (Master's dissertation). Available from University of Georgia Dissertations and Theses database.

35. Kollat, D.T. \& Willett, R.P. (1967). Consumer impulse purchasing behavior. Journal of Marketing Research, 4, 21-31.

36. Kotler, P. (1973-1974). Atmospherics as a Marketing Tool. Journal of Retailing. 49, (4), 1973-1974.

37. Kwekudee. (2012). Trip down memory lane. Retrieved December 03, 2012, from http:// Kwekudee- Trip down memory lane.blogspot.co.uk/2012/12/kente-cloth-ghanas-ashanti-cultural.html

38. Law, D., Wong, C., and Yip, J. (2012)."How does visual merchandising affect consumer affective response? An intimate apparel experience", European Journal of Marketing, Vol. 46 Iss: 1 pp. 112 - 133

39. Law, D. Wong, C., \& Yip, J. (2012). "How does visual merchandising affect consumer affective response? An intimate apparel experience", European Journal of Marketing, 46(1), 112 -133

40. Lea-Greenwood, G. (1998). "Visual merchandising: a neglected area in UK fashion retailing?” International Journal of Retailing \& Distribution Management, 18(4), 21-31.

41. Levi, E. \& Weitz, S. (2009). Retailing management. 7th Ed. New York: McGraw Hill.

42. Lindquist, J.D. (1974). "Meaning of image - a survey of empirical and hypothetical evidence",

43. Journal of Retailing, 50(4), 29-38. 
44. Macinnis, D.J. \& Price, L.L. (1987). "The role of imagery in information processing: review and extensions”, Journal of Consumer Research, 13,473-91.

45. Mandler, G. (1982). “The structure of value: accounting for taste”, in Clark, M.S. and Fiske, S.T. (Eds), Affect and Cognition, Lawrence Erlbaum, Hillsdale, NJ, pp. 3-36.

46. Manganari, E., Siomkos, G. \& Vrechopoulos, A. (2009). "Store atmosphere in web retailing”, European Journal of Marketing, 43(9), 1140-53 (special issue on E-Tailing).

47. Martineau, P. (1958). "The personality of the retail store”, Harvard Business Review, 36, 47-55.

48. McGoldrick, P. J. (2002). Retail marketing. Berkshire: McGraw-Hill Education, London

49. Meyers-Levy, J. \& Tybout, A.M. (1989). "Schema congruity as a basis for product evaluation”, Journal of Consumer Research, 16, 39-54.

50. Mills, K.H., Paul, J.E. \& Moorman, K.B., (1995). Applied visual merchandising (3rd Ed.).

51. Englewood Cliffs, New Jersey: Prentice-Hall.

52. Mitchell, V. (2001). "Re-conceptualizing consumer store image processing using perceived risk". Journal of Business Research, 54 (2), 167-72.

53. Ofori-Ansa, K. (2009). Histroty of Ashanti kente Cloth ---More than a Piece of fabric. Midwest Global, Inc. Retrieved August 4, 2013 from http://kente.midwesttradegroup.com/history.html

54. Omar, O. (1999), Retail Marketing, Pitman Publishing, London.

55. Porter, S.S. \& Claycomb, C. (1997), “The influence of brand recognition on retail store image”, Journal of Product \& Brand Management, 6(6), 373-87.

56. Saunders, M., Lewis, P., \& Thornhill, A. (2009). Research for Business Students. Pearson-Prenticehall. London.

57. Shu-Luan (n.d.). The Effect of Retail Store Disp lay Atmosphere on Consumer's Attention, Perceived Value, and Purchase Intention_A Case of Grid Shop in Taiwan.

58. Spies, K., Hesse, F. \& Loesch, K. (1997), “Store atmosphere, mood and purchasing behavior”, International Journal of Research in Marketing, 14 (1), 1-17.

59. Tesch, R. (1990). Qualitative research analysis tapes and software tools. New York: Wordsworth.

60. Tustin, D. H., Ligthelm, A., Martins, J. H. \& Van Wyk, H De J. (2005). Marketing research in practice. South Africa: ABC Press.

61. Wanninayake, W., \& Randiwela, P. (2007). The Impact of Visual Merchandising on consumer store choice decisions in Sri Lankan supermarkets. Paper presented at 7th Global Conference on Business \& Economics. Rome.

62. Walters, D., \& White, D. (1987). Retail Marketing Management. Basingstoke: MacMillan Press.

63. Wright, L.T., Newman, A. \& Dennis, C. (2006). “Enhancing consumer empowerment”, European Journal of Marketing, 40 (9/10), 925-35.

64. Zikmund, G. \& Babin, B. J. (2010). Exploring marketing research. 10th ed. China: South Western. 